\title{
Digestive enzyme activity in juvenile Nile tilapia (Oreochromis niloticus, L) submitted to different dietary levels of shrimp protein hydrolysate
}

\author{
Juliana Ferreira Santos • Patrícia Fernandes Castro • \\ Albino Luciani Gonçalves Leal • \\ Augusto Cézar Vasconcelos de Freitas Júnior • Daniel Lemos • \\ Luiz Bezerra Carvalho Jr. • Ranilson Souza Bezerra
}

Received: 13 October 2011 / Accepted: 22 August 2012/Published online: 6 September 2012

(C) Springer Science+Business Media B.V. 2012

\begin{abstract}
The effect of different dietary concentrations of shrimp protein hydrolysate (SPH) on digestive enzyme activity of Nile tilapia juveniles was evaluated. SPH concentrations in diets were $0,15,30$ and $60 \mathrm{~g} \mathrm{~kg}^{-1}$ (treatments SPH0, SPH15, SPH30 and SPH60, respectively). Hemoglobin, azocasein, BApNA ( $N \alpha$-benzoyl-DL-arginine- $p$-nitroanilide), SApNA (Suc-Ala-Ala-Pro-Phe $p$-nitroanilide), aminoacyl of $\beta$-naphthylamide and starch were used as substrates for enzyme activity determinations. The activity of total alkaline protease was significantly higher $(P<0.05)$ in fish under SPH15 and SPH60 treatments than in the control (SPH0). However, the effect was not dosedependent. Substrate-SDS-PAGE was also performed to evaluate changes in the profile
\end{abstract}

\footnotetext{
J. F. Santos · A. C. V. de Freitas Júnior · L. B. Carvalho Jr. · R. S. Bezerra ( $\)$ Laboratório de Enzimologia (LABENZ), Departamento de Bioquímica, Universidade Federal de Pernambuco, Cidade Universitária, Recife, PE CEP 50670-420, Brazil e-mail: ransoube@uol.com.br
}

J. F. Santos · A. C. V. de Freitas Júnior · L. B. Carvalho Jr. · R. S. Bezerra Laboratório de Imunopatologia Keizo Asami (LIKA), Universidade Federal de Pernambuco, Cidade Universitária, Recife, PE 50670-420, Brazil

\section{J. F. Santos}

Unidade Acadêmica de Serra Talhada, Universidade Federal Rural de Pernambuco, Fazenda Saco, S/N, Caixa Postal 063, Serra Talhada, PE CEP 56900-000, Brazil

P. F. Castro

Embrapa Meio-Norte, Caixa Postal 341, Parnaíba, PI 64200-970, Brazil

A. L. G. Leal

Companhia Hidro Elétrica do São Francisco (CHESF), Rua Delmiro Gouveia, 333, Bongi, Recife, PE 50761-901, Brazil

D. Lemos

Laboratório de Aqüicultura Marinha (LAM), Instituto Oceanográfico, Universidade de São Paulo, Cidade Universitária, São Paulo, SP 05508-120, Brazil 
of Nile tilapia digestive proteases caused by SPH. Substrate-SDS-PAGE revealed 12 active proteolytic bands, eight of which responded to SPH dietary incorporation. Inhibition substrate-SDS-PAGE indicated a decrease in the activity of three enzymes, with trypsin activity decreasing with the increase of SPH concentration, whereas the opposite occurred for two aminopeptidases. Distinct protease profiles were also found for each treatment, suggesting adaptability of digestive proteases from Nile tilapia to the different diets.

Keywords Digestive proteases and amylases - Nile tilapia - SDS-PAGE zymograms · Shrimp protein hydrolysate

\section{Introduction}

Tilapia production has increased significantly on a global scale in the last decade. This development has been followed by an increase in feed consumption, stimulating the search for new ingredients in diet formulations (Schulz et al. 2007). The growth of the aquaculture industry has generated large amounts of waste and by-products, which represent a challenge to the sustainability of the activity (Bezerra et al. 2001). Shrimp processing waste, for instance, may be disposed of in the environment, where it may potentially pollute water and land. By-products of terrestrial and aquatic farming systems may be processed into suitable ingredients and used as components in animal feeds, following biosecurity principles for feed applications. Shrimp processing waste has been identified as an animal protein source of great potential (Fanimo et al. 2000). A simple protocol for producing protein hydrolysate from white shrimp Litopenaeus vannamei (Boone) processing waste through autolysis has recently been developed (Cahú et al. 2012). This method renders a protein concentrate that is considered to be an excellent source of amino acids, with high levels of glutamate, aspartate, leucine, lysine, tyrosine and arginine (Leal et al. 2010). In fact, crustacean protein silage and hydrolysate have been used in fish feeds both as a new protein source (Plascência-Jatomea et al. 2002) and, in small amounts, as flavoring to enhance the attractiveness of feeds (Kolkovski et al. 2000).

Variations in the quality and quantity of nutrients used in diet formulations may modify enzymatic profile and activity in the digestive tract of animals (Lundstedt et al. 2004). Thus, feed composition could induce biological adaptations, including an increase in nutrient absorption (Moraes and Bidinotto 2000). Digestive enzymes have been investigated as a way of understanding nutritional requirements, and the effects of diet composition on enzyme activity in order to reduce feeding costs in fish farms (Caruso et al. 1996). Most studies thus far have evaluated the effect of different concentrations of protein, carbohydrates and lipids in feed formulations, correlating these results with enzyme activity, and differences in enzyme quality profile may be related to nutrient levels in the diet (Fountoulaki et al. 2005).

The present survey focuses on the following aspects: (a) the detectable changes in the activity of the main digestive enzymes caused by different concentrations of shrimp protein hydrolysate in tilapia feeds and (b) the use of substrate-SDS-PAGE zymograms as an effective tool to improve the analysis of these changes. 


\section{Materials and methods}

\section{Materials}

All reagents were of analytical grade and purchased from Sigma (St. Louis, MO, USA) and Merck (Darmstadt, Germany). The diets were prepared in Poytara LTDA (AraraquaraSão Paulo-Brazil).

\section{Shrimp protein hydrolysate production}

Shrimp head processing waste, comprising the cephalothorax without the body carapace, from L. vannamei juveniles (total body weight about 10-12 g) was provided by a local fishery processing plant (EMPAF Ltd.). SPH used in experimental diets was prepared according to Cahú et al. (2012). In total, approximately $20 \mathrm{~kg}$ of shrimp cephalothoraxes was obtained. The shrimp heads were washed and stored at $-20{ }^{\circ} \mathrm{C}$ in plastic bags containing $1 \mathrm{~kg}$ of the material. After that, the raw material was crushed in distilled water $(1: 1$ ratio; particle size approximately $5 \mathrm{~mm}$ ). The enzymatic autolysis (proteases from the shrimp midgut gland) occurred in a vessel placed in a water bath at $45 \pm 2{ }^{\circ} \mathrm{C}$ for $180 \mathrm{~min}$ with constant stirring $(700 \mathrm{rpm})$. The solution was then heated to $100{ }^{\circ} \mathrm{C}$ for $10 \mathrm{~min}$ in order to deactivate the enzymes, and the solid portion was strained through a $1.0-\mathrm{mm}$ sieve (Cahú et al. 2012). The resulting material was centrifuged at $10,000 \times g$ for $10 \mathrm{~min}$, and the supernatants (SPH) was stored in plastic bottles at $-20{ }^{\circ} \mathrm{C}$ until the preparation of the diets (Leal et al. 2010). The production method was similar to the industrial processes. Previously frozen-dried samples of SPH $(n=3)$ were used for proximate composition and AA analyses (Tables 1,2) in Protein Chemical Center of the Faculdade de Medicina de Ribeirão Preto, São Paulo, Brazil (AOAC 1984).

\section{Hydrolysis profile of SPH}

Enzymatic hydrolysis of SPH $\left(45^{\circ} \mathrm{C}\right)$ was followed by sampling at the incubation times of $0,30,60,90,120,150$ and $180 \mathrm{~min}$. The hydrolysis profile of shrimp protein hydrolysate (Aliquots of $100 \mu \mathrm{g}$ of protein, $n=3$ ) was evaluated in sodium dodecyl sulfate polyacrylamide gel electrophoresis (SDS-PAGE), using stacking gel at $4 \%(\mathrm{w} / \mathrm{v})$ and separation gel at $17 \%$ (Laemmli 1970). The gels were stained for protein overnight in $0.01 \%$ (w/v) Coomassie Brilliant Blue. The background of the gel was destained by washing in a solution containing $10 \%(\mathrm{v} / \mathrm{v})$ acetic acid and $25 \%(\mathrm{v} / \mathrm{v})$ methanol. The molecular mass of the protein bands was estimated using the 220-10 kDa molecular mass protein standards (Sigma).

Table 1 Proximate composition (\%) and energy of lyophilized shrimp protein hydrolisate

$\mathrm{SPH}$, from Litopenaeus vannmei (Leal et al. 2010)

\begin{tabular}{lr}
\hline Composition & Mean \\
\hline Moisture (\%) & 9.7 \\
Crude protein (\%) & 43.6 \\
Ether extract (\%) & 6.2 \\
Ash (\%) & 7.3 \\
Carbohydrate (\%) & 33.1 \\
Energy (Kcal $\left.100 \mathrm{~g}^{-1}\right)$ & 363.3 \\
\hline
\end{tabular}


Table 2 Amino acid composition of the shrimp protein hydrolisate

SPH from Litopenaeus vannamei (Leal et al. 2010)

\begin{tabular}{lrr}
\hline Amino acids & \multicolumn{2}{l}{$\mathrm{SPH}$} \\
\cline { 2 - 3 } & $\mathrm{mg} 100 \mathrm{~g}^{-1}$ & \\
\hline Essential & & \\
Arginine & $3400 \pm 0.043$ & 7.3 \\
Histidine & $1060 \pm 0.005$ & 2.3 \\
Isoleucine & $2000 \pm 0.021$ & 4.3 \\
Leucine & $3490 \pm 0.021$ & 7.4 \\
Lysine & $3350 \pm 0.000$ & 7.2 \\
Methionine & $1290 \pm 0.005$ & 2.7 \\
Phenylalanine & $2370 \pm 0.002$ & 5.1 \\
Threonine & $2120 \pm 0.031$ & 4.5 \\
Thryptophan & $670 \pm 0.016$ & 1.4 \\
Valine & $2250 \pm 0.012$ & 4.8 \\
Non-essential & & \\
Tyrosine & $3370 \pm 0.004$ & 7.2 \\
Aspartic acid & $4270 \pm 0.031$ & 9.1 \\
Glutamic acid & $5780 \pm 0.003$ & 6.2 \\
Glycine & $2890 \pm 0.005$ & 4.3 \\
Serine & $2030 \pm 0.001$ & 6.6 \\
Alanine & $3070 \pm 0.017$ & 6.3 \\
Proline & $2970 \pm 0.024$ & 0.9 \\
Cystine & $410 \pm 0.015$ & 100 \\
Total & 46790 & \\
\hline & & \\
\hline
\end{tabular}

Diets preparation

According to Leal et al. (2010), four isonitrogenous (37\% crude protein), isocaloric (total energy: $440 \mathrm{kcal} 100 \mathrm{~g}^{-1}$ ) experimental diets were formulated to feed Oreochromis niloticus juveniles (Table 3). Shrimp protein hydrolysate (SPH) was included in the diets at concentrations of 0 (control-SPH0), 15 (SPH15), 30 (SPH30) and $60 \mathrm{~g} \mathrm{~kg}^{-1}$ (SPH60), as a fed basis. A 1:2 animal/plant protein ratio (fishmeal and soybean meal, respectively) in the diets was established. SPH (liquid) was mixed with soybean meal, and the dough was dried at $65{ }^{\circ} \mathrm{C}$ for $24 \mathrm{~h}$. The ingredients were mixed and the diets prepared by extrusion under industrial conditions to obtain 1-mm diameter pellets.

\section{Animals and culture conditions}

Juvenile sex-reversed Nile tilapias were obtained from the Aquaculture Station of the Universidade Federal Rural de Pernambuco. The fish were stocked in fifteen 40-L glass aquaria ( 8 ind. per aquarium) equipped with a biological filter and continuous aeration and then submitted to a 7-day acclimatization period both for diets and experimental conditions in a completely randomized design, with four treatments and three replicates. The animals were kept in a photoperiod of 12:12 L:D. Prior to the feeding trial, fish were weighed $(1.7 \pm 0.4 \mathrm{~g})$ and measured $(4.7 \pm 0.4 \mathrm{~cm})$. Individuals were fed a ratio of $15,14,12,10$, 8 and $6 \%$ of biomass per day, adjusted every 9 days for a period of 45 days. Feed was 
Table 3 Composition and approximate analysis of the experimental diets

\begin{tabular}{|c|c|c|c|c|}
\hline \multirow[t]{2}{*}{ Ingredients (\%) } & \multicolumn{4}{|l|}{ Diets } \\
\hline & SPH 0 & SPH 15 & SPH 30 & SPH 60 \\
\hline Fish meal $(57 \% \mathrm{CP})$ & 23.0 & 22.0 & 21.0 & 18.0 \\
\hline Shrimp protein hydrolysate (SPH) & 0.0 & 1.5 & 3.0 & 6.0 \\
\hline Soybean meal (40.4 \% CP) & 47.0 & 47.5 & 47.5 & 47.5 \\
\hline Wheat meal & 16.0 & 13.5 & 13.5 & 15.5 \\
\hline Corn starch & 10.5 & 12.0 & 11.5 & 9.5 \\
\hline Soybean oil & 1.0 & 1.0 & 1.0 & 1.0 \\
\hline Dicalcium phosphate & 1.0 & 1.0 & 1.0 & 1.0 \\
\hline Mineral and vitamin $\operatorname{mix}^{\mathrm{a}}$ & 1.0 & 1.0 & 1.0 & 1.0 \\
\hline Salt & 0.5 & 0.5 & 0.5 & 0.5 \\
\hline Antioxidant BHT & 0.02 & 0.02 & 0.02 & 0.02 \\
\hline \multicolumn{5}{|c|}{ Proximate analysis (as-fed basis, $\mathrm{g} \mathrm{kg}^{-1}$ ) } \\
\hline Dry matter & 944.8 & 935.9 & 936.5 & 946.7 \\
\hline Crude protein & 371.9 & 374.3 & 376.2 & 380.6 \\
\hline Ether extract & 48.1 & 56.2 & 52.1 & 55.9 \\
\hline Crude fiber & 39.7 & 38.8 & 41.1 & 46.6 \\
\hline Ash & 105.7 & 102.9 & 101.6 & 101.9 \\
\hline Nitrogen-free extract & 434.6 & 427.8 & 429.0 & 435.0 \\
\hline Calcium & 22.2 & 21.7 & 20.0 & 17.2 \\
\hline Phosphorus & 12.4 & 12.5 & 12.6 & 12.8 \\
\hline Gross energy (kcal $\left.100 \mathrm{~g}^{-1}\right)^{\mathrm{b}}$ & 438.3 & 444.5 & 442.2 & 431.8 \\
\hline $\mathrm{P} / \mathrm{GE}$ ratio $\left(\mathrm{mg} \mathrm{kcal}^{-1}\right)$ & 84.9 & 84.1 & 84.6 & 88.0 \\
\hline
\end{tabular}

Leal et al. 2010

$C P$ crude protein, $B H T$ butylated hydroxytoluene

${ }^{a}$ Mineral and vitamin mix (quantity kg-1 premix): vitamin $\mathrm{A}(20,000 \mathrm{UI})$, vitamin $\mathrm{D}_{3}(5,000 \mathrm{UI})$, vitamin $\mathrm{E}$ $(250 \mathrm{mg})$, vitamin $\mathrm{K}_{3}(25 \mathrm{mg})$, vitamin $\mathrm{B}_{1}(37.5 \mathrm{mg})$, vitamin $\mathrm{B}_{2}(37.5 \mathrm{mg})$, vitamin $\mathrm{B}_{6}(25 \mathrm{mg})$, vitamin $\mathrm{B}_{12}(0.053 \mathrm{mg})$, vitamin $\mathrm{C}(250 \mathrm{mg})$, niacin $(200 \mathrm{mg})$, pantothenic acid $(100 \mathrm{mg})$, biotin $(1,25 \mathrm{mg})$, choline $(1000 \mathrm{mg})$, inositol $(250 \mathrm{mg}), \mathrm{Fe}(100 \mathrm{mg}), \mathrm{Cu}(12 \mathrm{mg}), \mathrm{Zn}(125 \mathrm{mg}), \mathrm{Mn}(37.5 \mathrm{mg})$, Se $(0.25 \mathrm{mg})$, I $(1.25 \mathrm{mg})$, Co $(0.25 \mathrm{mg})$

${ }^{\mathrm{b}}$ Estimate based on 5.65, 4.2 and $9.5 \mathrm{kcal} \mathrm{g}^{-1}$ for proteins, carbohydrates and lipids, respectively

offered 4 times per day. The fish accepted and fed on all diets over the experimental period (Leal et al. 2010).

The aquaria were siphoned twice a day to remove solids, with $66 \%$ water being replaced with clean water every day. Temperature $\left(28.7 \pm 0.59{ }^{\circ} \mathrm{C}\right)$, dissolved oxygen $\left(3.5 \pm 0.92 \mathrm{mg} \mathrm{L}^{-1}\right)$ and $\mathrm{pH}(8.1 \pm 0.19)$ were measured twice a day $(n=90)$. Ammonia $\left(0.14 \pm 0.22 \mathrm{mg} \mathrm{L}^{-1}\right)$ and nitrite $\left(0.08 \pm 0.02 \mathrm{mg} \mathrm{L}^{-1}\right)$ were monitored once a week $(n=6)$. Values are expressed as mean $\pm \mathrm{SE}$

Growth and nutrient utilization

The effects of SPH on the growth performance and nutrient utilization are shown in Table 4. Growth performance was evaluated through weight gain rate (WG), average daily gain (ADG), specific growth rate (SGR), feed conversion ratio (FCR), protein efficiency 
Table 4 Growth performance and nutrient utilization in Nile tilapia fed on diets containing shrimp protein hydrolysate instead of fish meal replacement

\begin{tabular}{|c|c|c|c|c|}
\hline Diets & SPH 0 & SPH 15 & SPH 30 & SPH 60 \\
\hline Initial weight (g) & $1.68 \pm 0.14$ & $1.72 \pm 0.07$ & $1.75 \pm 0.09$ & $1.81 \pm 0.06$ \\
\hline Final weight (g) & $27.18 \pm 2.43^{\mathrm{ns}}$ & $29.46 \pm 1.05^{\mathrm{ns}}$ & $26.02 \pm 3.07^{\mathrm{ns}}$ & $25.19 \pm 2.49^{\mathrm{ns}}$ \\
\hline Survival (\%) & $100.0^{\mathrm{ns}}$ & $100.0^{\mathrm{ns}}$ & $100.0^{\mathrm{ns}}$ & $100.0^{\mathrm{ns}}$ \\
\hline $\mathrm{WG}(\mathrm{g})^{\mathrm{a}}$ & $25.51 \pm 2.57^{\mathrm{ns}}$ & $27.73 \pm 1.11^{\mathrm{ns}}$ & $24.29 \pm 3.04^{\mathrm{ns}}$ & $23.39 \pm 2.49^{\mathrm{ns}}$ \\
\hline $\operatorname{ADG}\left(\mathrm{g} \mathrm{day}^{-1}\right)^{\mathrm{b}}$ & $0.57 \pm 0.10^{\mathrm{ns}}$ & $0.62 \pm 0.04^{\mathrm{ns}}$ & $0.54 \pm 0.12^{\mathrm{ns}}$ & $0.52 \pm 0.10^{\mathrm{ns}}$ \\
\hline $\operatorname{SGR}\left(\% \mathrm{day}^{-1}\right)^{\mathrm{c}}$ & $7.15 \pm 0.58^{\mathrm{ns}}$ & $7.38 \pm 0.10^{\mathrm{ns}}$ & $6.85 \pm 0.68^{\mathrm{ns}}$ & $6.73 \pm 0.57^{\mathrm{ns}}$ \\
\hline $\mathrm{FCR}^{\mathrm{d}}$ & $1.15 \pm 0.22^{\mathrm{ns}}$ & $1.09 \pm 0.16^{\mathrm{ns}}$ & $1.13 \pm 0.10^{\mathrm{ns}}$ & $1.17 \pm 0.12^{\mathrm{ns}}$ \\
\hline $\mathrm{PER}^{\mathrm{e}}$ & $2.26 \pm 0.39^{\mathrm{ns}}$ & $2.33 \pm 0.36^{\mathrm{ns}}$ & $2.20 \pm 0.18^{\mathrm{ns}}$ & $2.14 \pm 0.22^{\mathrm{ns}}$ \\
\hline ANPU $^{\mathrm{f}}$ & $39.31 \pm 3.90^{\mathrm{ns}}$ & $40.40 \pm 3.64^{\mathrm{ns}}$ & $38.59 \pm 1.84^{\mathrm{ns}}$ & $34.72 \pm 2.08^{\mathrm{ns}}$ \\
\hline
\end{tabular}

Leal et al. 2010

Different superscripts in the same column denote statistical differences $(P<0.05)$, and "ns" denotes no statistical differences. Values are mean $\pm \mathrm{SE}$ of five replicates

${ }^{a}$ Weight gain rate, ${ }^{b}$ Average daily gain, ${ }^{c}$ Specific growth rate, ${ }^{\mathrm{d}}$ Feed conversion ratio, ${ }^{\mathrm{e}}$ Protein efficiency ratio, ${ }^{\mathrm{f}}$ Apparent net protein utilization

ratio (PER) and apparent net protein utilization (ANPU) based on the following formulae: $\mathrm{WG}(\mathrm{g})=\mathrm{BW}_{f}-\mathrm{BW}_{i} ; \mathrm{ADG}=\mathrm{WG}(\mathrm{g}) /$ time (days); $\mathrm{SGR}=100\left(\mathrm{Ln} \mathrm{BW}_{f}-\mathrm{Ln} \mathrm{BW}_{i}\right) /$ time (days); FCR = dry feed offered $(\mathrm{g}) /$ wet weight gain $(\mathrm{g})$; PER = wet weight gain $(\mathrm{g}) /$ protein fed $(\mathrm{g})$; and $\mathrm{ANPU}=100\left[\left(\mathrm{BW}_{f} \times \mathrm{BCP}_{f}\right)-\left(\mathrm{BW}_{i} \times \mathrm{BCP}_{i}\right)\right] /(\mathrm{TF} \times \mathrm{CP})$, in which $\mathrm{BW}_{i}$ and $\mathrm{BW}_{f}=$ average initial and final body weight (g) of fish, respectively; $\mathrm{BCP}_{i}$

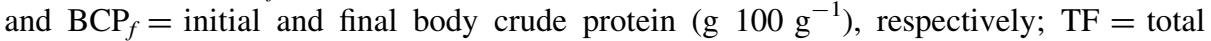
amount of diet fed $(\mathrm{g})$ and $\mathrm{CP}=$ crude protein of diet $\left(\mathrm{g} 100 \mathrm{~g}^{-1}\right)$ (Leal et al. 2010).

\section{Extraction of digestive enzymes}

At the end of trial, fish were left to fast for $24 \mathrm{~h}$, and six individuals from each replicate aquarium (divided into two replicates per aquarium) were removed and killed in an ice bath for biometric measurements and tissue removal, according to standard methodology (Bezerra et al. 2001). Stomach and intestines were immediately collected and homogenized (40 mg tissue $\mathrm{mL}^{-1}$ ) in $0.01 \mathrm{M}$ Glycine- $\mathrm{HCl} \mathrm{pH} 3.0$ and $0.01 \mathrm{M}$ Tris- $\mathrm{HCl} \mathrm{pH} 8.0$ buffers, respectively, containing $0.15 \mathrm{M} \mathrm{NaCl}$, using a tissue homogenizer. The resulting preparations were centrifuged at $10,000 \times g$ for $10 \mathrm{~min}$ at $4^{\circ} \mathrm{C}$ to remove cell debris and nuclei. The supernatants (crude enzyme extracts) were frozen at $-20{ }^{\circ} \mathrm{C}$ and used in further assays (Bezerra et al. 2005). Protein concentration was determined according to Bradford (1976) using bovine serum albumin (BSA) as the standard and reported as $\mathrm{mg}$ of protein equivalent to BSA.

Total acid proteolytic activity

Acid protease activity was evaluated using hemoglobin $(\mathrm{Hb})$ as the substrate as follows: in microcentrifuge tubes, $100 \mu \mathrm{L}$ of $2 \% \mathrm{Hb}$ in $0.06 \mathrm{M}$ Glycine- $\mathrm{HCl}$ buffer $\mathrm{pH} 3.0$ was mixed with $50 \mu \mathrm{L}$ stomach crude extract and $350 \mu \mathrm{L} 0.5 \mathrm{M}$ Glycine-HCl buffer $\mathrm{pH} 3.0$ for $60 \mathrm{~min}$ at $25{ }^{\circ} \mathrm{C}$. Five hundred microliters of $10 \%$ trichloroacetic acid (TCA) was then added to stop the reaction. After $15 \mathrm{~min}$, centrifugation was carried out at $8,000 \times g$ for 
10 min. The absorbance of supernatant $(70 \mu \mathrm{L})$ was measured at $280 \mathrm{~nm}$ (Bio-Rad SmartSpec 3000, USA) versus a similarly prepared blank in which $0.01 \mathrm{M}$ Glycine-HCl buffer pH 3.0 replaced the crude extract sample, based on a methodology adapted from Díaz-López et al. (1998). Previous experiments showed that, for the first $60 \mathrm{~min}$, the reaction carried out under the conditions described above followed first-order kinetics. One unit (U) of enzyme activity was defined as the amount of enzyme capable of hydrolyzing hemoglobin to produce a 0.001 change in absorbance per minute per milligram of protein.

\section{Total alkaline proteolytic activity}

In microcentrifuge tubes, $1 \%$ azocasein prepared in $0.1 \mathrm{M}$ Tris- $\mathrm{HCl}$ buffer $\mathrm{pH} 8.0$ was incubated with intestine crude enzyme extract $(30 \mu \mathrm{L})$ for $60 \mathrm{~min}$ at $25{ }^{\circ} \mathrm{C}$. Two hundred and forty $\mu \mathrm{L}$ of $10 \%$ trichloroacetic acid (TCA) was then added to stop the reaction. After $15 \mathrm{~min}$, centrifugation was carried out at $8,000 \times g$ for $5 \mathrm{~min}$. The supernatant $(70 \mu \mathrm{L})$ was added to $1 \mathrm{M} \mathrm{NaOH}(130 \mu \mathrm{L})$ in a 96-well microtiter plate, and the absorbance of this mixture was measured in a microtiter plate reader (Bio-Rad 680, Japan) at $450 \mathrm{~nm}$ versus a similar prepared blank in which $0.01 \mathrm{M}$ Tris- $\mathrm{HCl} \mathrm{pH} 8.0$ replaced the crude extract sample. One unit (U) of enzyme activity was defined as the amount of enzyme capable of hydrolyzing azocasein to produce a 0.001 change in absorbance per minute per milligram of protein (Bezerra et al. 2005).

\section{Trypsin and chymotrypsin activity}

The activity of trypsin and chymotrypsin was determined using $8.0 \mathrm{mM}$ BApNA $(N \alpha-$ benzoyl-DL-arginine- $p$-nitroanilide) and $8.0 \mathrm{mM}$ SApNA (Suc-Ala-Ala-Pro-Phe $p$-nitroanilide) in DMSO (dimethyl sulfoxide), respectively. Intestine crude enzyme extract $(30 \mu \mathrm{L})$ was incubated with $0.1 \mathrm{M}$ Tris- $\mathrm{HCl}$ buffer $\mathrm{pH} 8.0(140 \mu \mathrm{L})$ and respective substrates $(30 \mu \mathrm{L})$ in a microtiter plate reader (Bio-Rad 680, Japan). Absorbance was measured at $405 \mathrm{~nm}$ versus a similar prepared blank in which $0.1 \mathrm{M}$ Tris- $\mathrm{HCl} \mathrm{pH} 8.0$ replaced the crude extract sample. Enzyme activity was determined in triplicate. Trypsin and chymotrypsin units of activity were expressed as a change in absorbance per minute per milligram of protein (Bezerra et al. 2005).

\section{Aminopeptidase activity}

Aminopeptidase activity was evaluated using aminoacyl of $\beta$-naphthylamide (AA of arginine) as substrate. The procedure adapted from Oliveira et al. (1999) was carried out in triplicate, by incubating $4.2 \mathrm{mM}$ substrate $(50 \mu \mathrm{L}), 50.0 \mathrm{mM}$ sodium phosphate buffer $\mathrm{pH}$ $7.0(600 \mu \mathrm{L})$ and deionised $\mathrm{H}_{2} \mathrm{O}(50 \mu \mathrm{L})$ at $37^{\circ} \mathrm{C}$. After temperature equilibration, intestine crude extract $(50 \mu \mathrm{L})$ was added, and 30 min later, the reaction was stopped by adding $1 \mathrm{mg} \mathrm{mL}^{-1}$ fresh Garnet reagent $(250 \mu \mathrm{L})$ in $0.2 \mathrm{M}$ sodium acetate buffer $\mathrm{pH} 4.2$ containing $10 \%$ Tween 20 (v/v). After 10 min, absorbance was measured at $525 \mathrm{~nm}$ (BioRad SmartSpec 3000, USA), and the amount of $\beta$-naphthylamine was determined using a standard $\beta$-naphthylamine curve. Activity was expressed as protease $\mathrm{mU} \mathrm{mg}^{-1}$ of protein. One unit of enzyme activity was defined as the amount of enzyme required to hydrolyze one $\mu \mathrm{mol}$ of $p$-nitroaniline per minute per milligram of protein. 
Amylase activity

Amylase activity was evaluated according to Bernfeld (1955) using $2 \%$ starch as unspecific substrate: $60 \mu \mathrm{L}$ intestine crude extract were incubated with $375 \mu \mathrm{L}$ starch solution and $375 \mu \mathrm{L} 10 \mathrm{mM}$ phosphate buffer $\mathrm{pH} 8.0$ containing $15 \mathrm{mM} \mathrm{NaCl}$ at $25{ }^{\circ} \mathrm{C}$. After $20 \mathrm{~min}$, 3.5-dinitro salicylic acid (DNSA) was added and the solution was heated to $100{ }^{\circ} \mathrm{C}$ for $10 \mathrm{~min}$. After temperature equilibration, absorbance was measured at $570 \mathrm{~nm}$ (Bio-Rad SmartSpec 3000, USA) versus a similarly prepared blank in which $10 \mathrm{mM}$ phosphate buffer replaced the crude extract sample. Enzyme activity was determined in triplicate. One unit of enzyme activity was defined as the amount of enzyme required to liberate $1 \mathrm{mg}$ of maltose per milligram of protein per min.

Enzyme characterization in substrate-SDS-PAGE

Proteases from intestine crude extract of $O$. niloticus (Aliquots of $50 \mu \mathrm{g}$ of protein, $n=3$ ) were studied in substrate sodium dodecyl sulfate polyacrylamide gel electrophoresis (SDSPAGE) using stacking gel at $4 \%(\mathrm{w} / \mathrm{v})$ and separation gel at $12.5 \%$ (Laemmli 1970).

Zymograms of protease activity were carried out based on Garcia-Carreño et al. (1993). After electrophoresis, the gels were immersed in $2.5 \%$ Triton X-100 dissolved in $0.1 \mathrm{M}$ Tris- $\mathrm{HCl}$ buffer $\mathrm{pH} 8.0$ to remove the SDS and incubated with $3 \%$ casein $(\mathrm{w} / \mathrm{v})$ in $0.1 \mathrm{M}$ Tris- $\mathrm{HCl}$ buffer $\mathrm{pH} 8.0$ for $30 \mathrm{~min}$ at $4{ }^{\circ} \mathrm{C}$. The temperature was raised to $37{ }^{\circ} \mathrm{C}$ and maintained at this value for 90 min to allow the digestion of casein by the active fractions. Finally, the gel was stained overnight for protein in $0.18 \%$ (w/v) Coomassie Brilliant Blue R250 prepared in acetic acid and methanol (10:25\% v/v), and the background of the gel was distained in acetic acid and methanol (10:25\% v/v). Clear bands in blue background denoted protease bands by digestion of casein substrate.

Inhibition assays using substrate-SDS-PAGE

The following inhibitors prepared in DMSO at a final concentration of $2 \mathrm{mM}$ were used: Tosyl phenylalanine chlorometyl ketone (TPCK—chymotrypsin inhibitor); Phenyl-methylsulfonil-fluoride (PMSF - serine proteases inhibitor); benzamidine and tosyl-lysine chloromethyl ketone (TLCK), both trypsin inhibitors; and bestatin (leucine aminopeptidase inhibitor). For the inhibition study, only the crude extracts from animals under SPHO treatment $(n=3)$ were used, since all caseinolytic bands were found in this treatment. Samples of enzyme extract $(100 \mu \mathrm{L})$ and inhibitors $(100 \mu \mathrm{L})$ were incubated at $25{ }^{\circ} \mathrm{C}$ for $30 \mathrm{~min}$. An aliquot of $50 \mu \mathrm{g}$ of protein was collected and applied on each respective lane. After that, the zymogram was performed as described above. The $100 \%$ values (control) were established using DMSO without inhibitors (Lemos et al. 2002, 2004).

Statistical analysis

All data were tested for normal distribution (Shapiro-Wilk test) and homogeneity of variances (Bartlett's test). One-way analysis of variance (ANOVA) by Tukey test was used for normally distributed data, whereas Kruskal-Wallis test was used for non-normally distributed data. Differences were reported as statistically significant when $P<0.05$, using the SysEapro software (beta version). 


\section{Results}

Figure 1 shows the hydrolysis profile of SPH. Enzymatic autolysis (proteases from the shrimp midgut gland) visibly promoted the digestion of proteins with the greatest molecular mass over time. At time 0 , most proteins had molecular mass between 15 and $70 \mathrm{kDa}$, at time $150 \mathrm{~min}$, most proteins were smaller than $15 \mathrm{kDa}$.

Table 5 shows the enzyme activities in the crude extracts. Statistical differences $(P<0.05)$ between animals fed the experimental diets (SPH0, SPH15, SPH30 and SPH60) were only observed for total alkaline proteases.

Substrate-SDS-PAGE zymograms revealed caseinolytic activity in crude extracts of fish from all treatments (Fig. 2). Twelve caseinolytic bands were found in animals fed on SPHO and were named P1 to P12, showing the highest number of active bands among treatments. Proteases P1 to P4 were not significantly affected by the addition of the protein hydrolysate, but P5 to P12 underwent alterations in the caseinolytic pattern. As the concentration of hydrolysate increased, there was a decrease in the activity of proteases P6, P7 and P8. The opposite occurred for P5, P9, P10, P11 and P12, in which the caseinolytic bands proved more intense.

The effect of specific inhibitors on the caseinolytic bands from fish crude enzyme extract is shown in Fig. 3. As observed in Fig. 2, the zymogram of the crude extract (SPH0) without inhibitors (control) revealed 12 caseinolytic bands. TPCK did not significantly affect the caseinolytic activity of $O$. niloticus enzymes, and P11 was the only

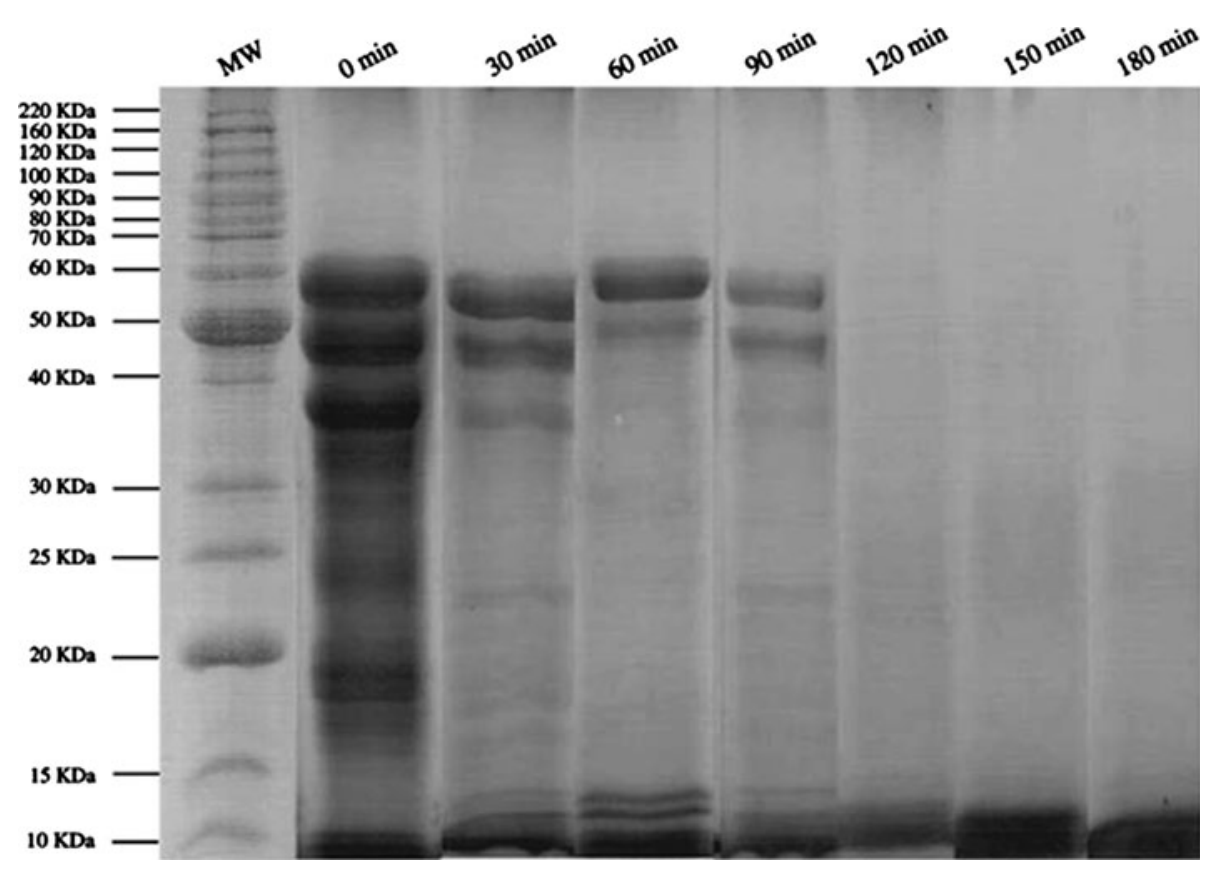

Fig. 1 Hydrolysis profile of shrimp protein hydrolysate (using autolysis) in sodium dodecyl sulfate polyacrylamide gel electrophoresis (SDS-PAGE) using stacking gel at $4 \%$ (w/v) and separation gel at $17 \%$. Lanes correspond to molecular mass marker (MM) and incubation times of 0, 30, 60, 90, 120, 150 and $180 \mathrm{~min}$ of enzymatic hydrolysis. SPH was produced through autolysis of Litopenaeus vannamei cephalothorax (heads) 
Table 5 Digestive enzyme activity of crude extracts recovered from stomach (acid) and intestine of juvenile Nile tilapia $O$. niloticus fed on experimental diets containing increasing shrimp protein hydrolysate levels $\left(0-60 \mathrm{~g} \mathrm{~kg}^{-1}\right)$

\begin{tabular}{|c|c|c|c|c|c|c|}
\hline Diets & $\begin{array}{l}\text { Acid proteolytic } \\
\text { activity }\end{array}$ & $\begin{array}{l}\text { Alkaline } \\
\text { proteolytic } \\
\text { activity }\end{array}$ & Trypsin & Chymotrypsin & Aminopeptidase & Amylase \\
\hline $\begin{array}{c}\text { SPH } \\
0\end{array}$ & $155.84 \pm 14.22^{\mathrm{ns}}$ & $11.80 \pm 0.55^{\mathrm{b}}$ & $2.58 \pm 0.09^{\mathrm{ns}}$ & $22.70 \pm 1.26^{\mathrm{ns}}$ & $41.68 \pm 3.32^{\mathrm{ns}}$ & $45.47 \pm 3.92^{\mathrm{ns}}$ \\
\hline $\begin{array}{r}\text { SPH } \\
15\end{array}$ & $111.38 \pm 22.83^{\mathrm{ns}}$ & $15.35 \pm 0.76^{\mathrm{a}}$ & $3.38 \pm 0.17^{\mathrm{ns}}$ & $39.74 \pm 3.94^{\mathrm{ns}}$ & $45.34 \pm 1.63^{\mathrm{ns}}$ & $53.50 \pm 4.65^{\mathrm{ns}}$ \\
\hline $\begin{array}{r}\text { SPH } \\
30\end{array}$ & $162.49 \pm 16.69^{\mathrm{ns}}$ & $13.60 \pm 0.73^{\mathrm{ab}}$ & $2.82 \pm 0.20^{\mathrm{ns}}$ & $30.89 \pm 2.42^{\mathrm{ns}}$ & $47.66 \pm 2.08^{\mathrm{ns}}$ & $48.79 \pm 4.82^{\mathrm{ns}}$ \\
\hline $\begin{array}{r}\text { SPH } \\
60\end{array}$ & $132.19 \pm 13.14^{\mathrm{ns}}$ & $15.23 \pm 0.88^{\mathrm{a}}$ & $2.62 \pm 0.15^{\mathrm{a}}$ & $36.66 \pm 3.60^{\mathrm{ns}}$ & $39.85 \pm 2.61^{\mathrm{ns}}$ & $56.77 \pm 4.31^{\mathrm{ns}}$ \\
\hline
\end{tabular}

Acid and alkaline proteolytic activity expressed as $\mathrm{U}$ mg of Protein $(\mathrm{P})^{-1}$; trypsin, chymotrypsin and aminopep-

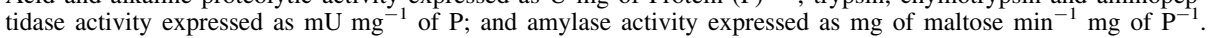
Different superscripts in the same column denote statistical differences $(P<0.05)$, and "ns" denotes no statistical differences. Values are mean $\pm \mathrm{SE}$ of five replicates

enzyme inhibited by TPCK. PMSF revealed high inhibition of P9 and P11 caseinolytic bands. Benzamidine completely inhibited P6 and P8 bands. One band between P5 and P6 enzymes (white arrow) revealed activity in the presence of benzamidine, but it did not appear in the control. TLCK strongly inhibited P3, P4, P6, P7, P8 and P11. Bestatin totally inhibited seven digestive enzyme bands of 0 . niloticus (P3, P4, P5, P6, P7, P8 and P9). Inhibitors had no effect on P1, P2, P10 and P12 caseinolytic bands.

\section{Discussion}

As can be observed in Fig. 1, autolysis efficiently solubilized and hydrolyzed protein from shrimp processing waste (cephalothorax section) and produced protein hydrolysate, which was shown to be a promising protein feedstuff for tilapia.

Fig. 2 Zymogram of digestive proteases $(3 \%$ casein as substrate) of intestine enzyme extracts from juvenile Nile tilapia $O$. niloticus fed on diets containing different concentrations of shrimp protein hydrolysate (SPH). Lanes correspond to dietary SPH inclusion (\%): SPH 0, SPH 1.5, SPH 3 and SPH 6. Further details in "Materials and methods"

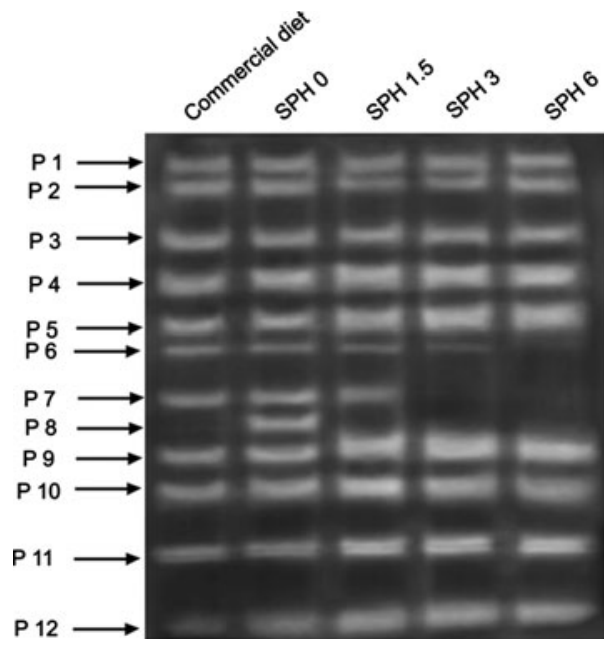


Hydrolysis using exogenous substances allows better control of the properties of the resulting products. However, the cost of the substances (enzymes, acids and solvents) is an obstacle to the viability of the process. Autolysis is an enzymatic process that can be used as an alternative to processes that employ exogenous substances to recover bioactive molecules, such as chitin (for chitosan production) and carotenoids (Armenta and Guerrero-Legarreta 2009; Chen et al. 2011; Cahú et al. 2012). Moreover, autolysis is a common method used to treat fish and shrimp waste, since it does not use any exogenous chemical or biological additive, for example silage. The degree of hydrolysis affects certain product properties, like viscosity, solubility and the partition of proteins. These, in turn, influence the absorption capacity and rate of passage of the diet through the gastrointestinal tract. The solubility of the hydrolysates depends on the nature of the raw material, method, temperature and hydrolysis time (Kotzamanis et al. 2007). Plascência-Jatomea et al. (2002) reported that the acidic conditions in which fermentative shrimp silage hydrolysate is produced cause the loss of labile nutrients, such as tryptophan. Although the two products have a very similar essential amino acid composition, the SPH produced here proved to be an adequate source of tryptophan, as well as lysine, leucine, arginine, phenylalanine and valine (Leal et al. 2010).

The use of hydrolyzed protein in diets for aquatic animals involves some particularities that should be taken into account. For example, diets with high content of hydrolyzed protein can lead to a loss of nutrients by lixiviation, because it contains high levels of small peptides that are usually more soluble (Leal et al. 2010). The extent of hydrolysis can result in protein hydrolysates with different contents of amino acids, di- and tripeptides, oligopeptides, polypeptides and proteins, which will ultimately result in differences in the quality of the diet.

The nutritional value of a diet is not based simply on its chemical composition, but also on the ability physiological fish to digest and absorb, according to these animals' eating habits. During digestion, these proteins are broken down into simpler compounds (peptides and free amino acids) and then are absorbed by specific membrane proteins specialized in peptide transport (e.g., PepT1) and utilized by the body (Sangaletti et al. 2009; Terova et al. 2009; Verri et al. 2011). This degradation in the digestive tract is performed with the assistance of enzymes. A number of authors have analyzed digestive enzyme activity in aquatic organisms and dietary composition, reporting divergent results. Nagase (1964) and Kohla et al. (1992) found enhanced trypsin activity, corresponding to an increase in

Fig. 3 Inhibition zymogram of digestive proteases (3\% casein as substrate) of intestine enzyme extracts from juvenile Nile tilapia $O$. niloticus fed the SPH 0 diet. Lanes correspond to treatments: control without inhibitors, TPCK, PMSF, Benzamidine, TLCK and Bestatin. Further details in "Materials and methods" and Fig. 2

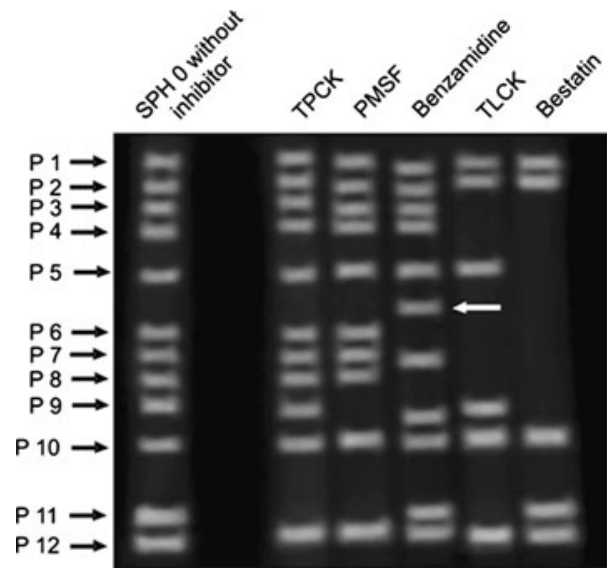


feeding rates for the species Mozambique tilapia, Oreochromis mossambicus (Peters) and Colossoma macropomum (Cuvier), respectively. Papoutsoglou and Lyndon (2006) found an increase in chymotrypsin activity in Spotted wolfish, Anarhichas minor (Olafsen), when the protein concentration was reduced, indicating the adaptation of this species to low protein concentrations as a way to better absorb nutrients from the diet. Studies about the effect of protein hydrolysates on the digestive enzymes from aquatic organisms are available in the literature (Córdova-Murueta and García-Carreño 2002; Cahu et al. 2004; Zambonino Infante and Cahu 2007). However, there is little information regarding the specific effects of dietary supplementation with shrimp protein hydrolysate on the digestive enzymes in Nile tilapia.

In the present paper, no statistical differences in proteases activities were observed among the SPH 0 (control) and treatments with higher concentrations of SPH (SPH15, SPH30 and SPH60) (Table 5), or in growth parameters (final weight, survival, weight gain, average daily gain, specific growth rate, feed conversion ratio, protein efficiency ratio, or apparent net protein utilization) (Table 4) (Leal et al. 2010). Only the activity of total alkaline protease was significantly higher $(P<0.05)$ in the fish under SPH15 and SPH 60 treatments, when compared to SPH0 (control) (Table 5). No correlation was observed between different concentrations of hydrolysate in the diets and the activity of any of the enzymes studied.

European seabass, Dicentrarchus labrax (L) were fed diets containing enzymatic hydrolyzed replacement for fish meal (native protein) in the proportions of 0,20 and $40 \%$. Zambonino Infante et al. (1997) demonstrated that fish to the trypsin activity was enhanced by the native protein, whereas chymotrypsin activity was enhanced by the diets containing di- and tripeptides. On the other hand, Kotzamanis et al. (2007) also evaluated the inclusion effect of protein hydrolysate on the digestive enzyme activities in European seabass, D. labrax larvae fed on diets with 10 and $19 \%$ protein hydrolysate. They found no statistical differences in amylase and trypsin activity between treatments. However, aminopeptidase activity was higher when $10 \%$ protein hydrolysate was administered. Thus, the absence of statistical difference found for most enzymes, and growth parameters can be related to the loss of SPH by lixiviation. In addition, commercial substrates used in this study showed no sensitivity to detect differences in most of the enzymatic activities; in other words, it was observed that the effects of SPH on the digestive enzymes were comparably small and not dose-dependent.

The different results observed in the literature and those obtained here led us to consider other methods. The zymograms afforded to observe the dose-dependent effect of SPH on some proteases (caseinolytic bands). In fact, zymograms appear to be a more sensitive biochemical tool in comparison with other methods for detecting the proteinase composition of crude extracts from tissues and to allow the determination of enzyme activity zones (Garcia-Carreño et al. 1993).

Through analyses of inhibition zymograms, it was possible to determine the following: one caseinolytic band with aminopeptidase activity (inhibited only by Bestatin, P5) and probably another aminopeptidase (P9) inhibited by Bestatin and by PMSF; some other active bands, P3, P4, P6, P7, P8 and P11, seemed to be proteases of low specificity, with trypsin/aminopeptidase activity (P3, P4, P6, P7 and P8 which were inhibited by trypsin inhibitors and by Bestatin) and chymotrypsin/trypsin activity (P11 which was inhibited by PMSF, TPCK and TLCK). It was not possible to identify P1, P2, P10 and P12, as none of the inhibitors had any effect on these proteases. Comparing the zymogram of enzyme activity according to dietary treatment to the inhibition gel, at increased concentration of shrimp protein hydrolysate, there was an overall slowdown of proteases with trypsin 
activity (P6, P7 and P8). On the other hand, it was identified that the caseinolytic bands P5 and P9 (identified as aminopeptidase activity, Fig. 3) grew in intensity with increasing SPH contents. The caseinolytic bands P10 and P12 (not identified) and P11 (with chymotrypsinlike/trypsin-like activity) also exhibited an increase in intensity with the inclusion of SPH in the diet. Cahu et al. (2004) found that trypsin secretion was higher in larvae of the D. labrax fed on diets with $14 \%$ protein hydrolysate, being reduced with increasing concentrations (46\%).

Zymograms in Figs. 2 and 3 show that the classical protease inhibitors herein employed were not effective upon some caseinolytic bands (P1, P2, P10 and P12), and in some cases, the inhibitory effect was not conclusive (P3, P4, P6, P7, P8, P9 and P11), suggesting a low compatibility of these enzymes with mammalian proteases. In fact, these commercial inhibitors are generally synthesized based on the mammalian enzyme mechanism, and as the fish digestive system may be considerably different from that of mammals, differences in the mechanisms of their enzymes may also occur. In spite of the results of the present work, tilapia digestive enzymes were not considerably affected by classical trypsin inhibitors. Bezerra et al. (2005) showed that purified Nile tilapia trypsin could be strongly inhibited by TLCK and Benzamidine. PMSF was shown able to inhibit about $50 \%$ of trypsin activity.

Although there were differences in digestive enzyme activity (total alkaline proteases) between fish fed different experimental diets, there was no clear relationship between enzyme activity and different concentrations of shrimp protein hydrolysate in these diets. Substrate-SDS-PAGE zymogram proved to be efficient in detecting changes in enzyme activity in fish submitted to different diets. Through this method, different protease profiles could be detected according to experimental diet. These data underscore the suggested ability of tilapia to adapt to different food sources. Actually, as an omnivorous opportunistic fish, tilapia is able to assimilate nutrients from different sources, like benthic algae, phytoplankton, macrophytes, zooplankton, small invertebrates, detritus and cyanobacteria. The feed choice is mainly related to the availability of food items in the environment (Bowen 1982; Fitzsimmons 1997; Stickney 1997; Beveridge and Baird 2000; LoweMcConnell 2000). To benefit from all these sources, the enzyme arsenal of tilapia should be diverse enough to digest the wide range of ingested food.

Acknowledgments The authors would like to thank Albérico Espírito Santo and João Virgínio for their technical assistance and Poytara Ltda for the preparation of the diets. This study was supported by the Financiadora de Estudos e Projetos (FINEP/RECARCINE), Ministério de Aquicultura e Pesca-(MAP), Empresa Brasileira de Pesquisa Agropecuária (EMBRAPA), Conselho Nacional de Pesquisa e Desenvolvimento Científico (CNPq), Fundação de Apoio à Ciência e Tecnologia do Estado de Pernambuco (FACEPE), Petróleo do Brasil S/A (PETROBRAS) and the Coordenação de Aperfeiçoamento de Pessoal de Nível Superior (CAPES). D. Lemos received funding from FAPESP (05/50578-2; 07/07051-9) and CNPq/ SEAP (504031/03-1; 308444/06-0; 474222/07-1).

\section{References}

AOAC (1984) Official methods of analysis, 12th edn. Association of Official Analytical Chemists, Washington, DC

Armenta RE, Guerrero-Legarreta I (2009) Amino acid profile and enhancement of the enzymatic hydrolysis of fermented shrimp carotenoproteins. Food Chem 112:310-315

Bernfeld P (1955) Amylases, $\alpha$ and $\beta$. In: Colowick SP, Kaplan NO (eds) Methods in enzymology, vol 1. Academic Press, New York

Beveridge MCM, Baird DJ (2000) Diet, feeding and digestive physiology. In: Beveridge MCM, McAndrew BJ (eds) Tilapias: biology and exploitation. Kluwer Academic Publishers, Great Britain 
Bezerra RS, Santos JF, Paiva PMG, Correia MTS, Coelho LCBB, Vieira VLA, Carvalho LB Jr (2001) Partial purification and characterization of a thermostable trypsin from pyloric caeca of tambaqui (Colossoma macropomum). J Food Biochem 25:199-210

Bezerra RS, Lins EJF, Alencar RB, Paiva PMG, Chaves MEC, Coelho LCBB, Carvalho LB Jr (2005) Alkaline proteinase from intestine of Nile tilapia (Oreochromis niloticus). Process Biochem 40: 1829-1834

Bowen SH (1982) Feeding, digestion and growth-qualitative consideration. In: Pullin RS, Lowe-McConnell VRH (eds) The biology and culture of tilapias. ICLARM, Manilla

Bradford MM (1976) A rapid and sensitive method for the quantification of microgram quantities of protein utilizing the principle of protein binding. Anal Biochem 72:248-254

Cahu C, Rønnestad I, Grangier V, Zambonino Infante JL (2004) Expression and activities of pancreatic enzymes in developing sea bass larvae (Dicentrarchus labrax) in relation to intact and hydrolyzed dietary protein; involvement of cholecystokinin. Aquaculture 238:295-308

Cahú TB, Santos SD, Mendes A, Córdula CR, Chavante SF, Carvalho Jr. LB, Nader HB, Bezerra RS (2012). Recovery of protein, chitin, carotenoids and glycosaminoglycans from Pacific white shrimp (Litopenaeus vannamei) processing waste. Process Biochem 47:570-577

Caruso G, Genovese L, Greco S (1996) Preliminary investigation on the digestive enzyme of reared Pagellus acarne (Riso, 1826) juveniles in relation to two different diets. Oebalia 22:3-13

Chen X, Fang X, Jiang Y, Chen J, Yu H, Liao Z (2011) Hydrolysis to recover protein for efficient utilization of shrimp waste. Int Conf Comput Distrib Control Intell Environ Monit. doi:10.1109/CDCIEM. 2011.138

Córdova-Murueta JH, García-Carreño FL (2002) Nutritive value of squid and hydrolyzed protein supplement in shrimp feed. Aquaculture 210:371-384

Díaz-López M, Moyano-López FJ, Alarcón-López FJ, García-Carreño FL, Navarrete Del Toro MA (1998) Characterization of fish acid proteases by substrate-gel electrophoresis. Comp Biochem Physiol B 121:369-377

Fanimo AO, Oduguwa OO, Onifade AO, Olutunde TO (2000) Protein quality of shrimp-waste meal. Bioresour Technol 72:185-188

Fitzsimmons K (1997) Introduction to tilapia nutrition. In: Fitzsimmons K (ed) Tilapia aquaculture, vol 1. Northeast Regional Agricultural Engineering Service, New York

Fountoulaki E, Alexis MN, Nengas I, Venou B (2005) Effect of diet composition on nutrient digestibility and digestive enzyme levels of gilthead sea bream (Sparus aurata L.). Aquac Res 36: 1243-1251

Garcia-Carreño FL, Dimes LE, Haard NF (1993) Substrate-gel electrophoresis for composition and molecular weight of proteinases or proteinaceous proteinase inhibitors. Anal Biochem 214:65-69

Kohla U, Saint-Paul U, Friebe J, Wernicke D, Hilge V, Braum E, Gropp J (1992) Growth, digestive enzyme activities and hepatic glycogen levels in juvenile Colossoma macropomum, Cuvier, 1818, from South America during feeding, starvation and refeeding. Aqualc. Fish. Manag. 23:189-208

Kolkovski S, Czesny S, Dabrowski K (2000) Use of krill hydrolysate as a feed attractant for fish larvae and juveniles. J. World Aquac. Soc. 31:81-88

Kotzamanis YP, Gisbert E, Gatesoupe FJ, Zambonino-Infante JL, Cahu C (2007) Effects of different dietary levels of fish protein hydrolysates on growth, digestive enzymes, gut microbiota, and resistance to Vibrio anguillarum in European sea bass (Dicentrarchus labrax) larvae. Comp Biochem Physiol A 147:205-214

Laemmli UK (1970) Cleavage of structural proteins during the assembly of the head of bacteriophage T4. Nature 227:680-685

Leal ALG, Castro PF, Lima JPV, Correia SE, Bezerra RS (2010) Use of shrimp protein hydrolysate in Nile tilapia (Oreochromis niloticus, L.) feeds. Aquac Int 18:635-646

Lemos D, Garcia-Carreño FL, Hernández P, Navarrete-del-Toro A (2002) Ontogenic variation in digestive proteinase activity, RNA and DNA content of larval and postlarval white shrimp Litopenaeus schmitti. Aquaculture 214:363-380

Lemos D, Córdova-Murueta J, Navarrete-del-Toro A, Garcia-Carreño FL (2004) Testing feeds and feed ingredients for juvenile pink shrimp Farfantepenaeus paulensis: in vitro determination of protein digestibility and proteinase inhibition. Aquaculture 239:307-321

Lowe-McConnell RH (2000) The roles of tilapias in ecosystems. In: Beveridge MCM, McAndrew BJ (eds) Tilapias: biology and exploitation. Kluwer Academic Publishers, Great Britain

Lundstedt LM, Melo JFB, Moraes G (2004) Digestive enzymes and metabolic profile of Pseudoplatystoma corruscans (Teleostei: Siluriformes) in response to diet composition. Comp Biochem Physiol B 137:331-339 
Moraes G, Bidinotto P (2000) Induced changes in the amylohydrolytic profile of the gut of Piaractus mesopotamicus (Holmberg, 1885) fed different levels of soluble carbohydrate: its correlation with metabolic aspects. Rev Ictiol 8:47-51

Nagase G (1964) Contribution to the physiology of digestion in Tilápia mosambica digestive enzymes and effects of diets on their activity. Z Vgl Physiol 49:270-284

Oliveira SM, Freitas JO, Alves KB (1999) Rabbit kidney aminopeptidases: purification and some properties. Immunopharmacology 45:215-221

Papoutsoglou ES, Lyndon AR (2006) Digestive enzymes of Anarhichas minor and the effect of diet composition on their performance. J Fish Biol 69:446-460

Plascência-Jatomea M, Olvera-Novoa MA, Arredondo-Figueroa JL, Hall GM, Shirai K (2002) Feasibility of fishmeal replacement by shrimp head silage protein hydrolysate in Nile tilapia (Oreochromis niloticus L) diets. J Sci Food Agric 82:753-759

Sangaletti R, Terova G, Peres A, Bossi E, Corà S, Saroglia M (2009) Functional expression of the oligopeptide transporter PepT1 from the sea bass (Dicentrarchus labrax). Pflugers Arch Eur J Physiol 459:47-54

Schulz C, Wickert M, Kijora C, Ogunji J, Rennert B (2007) Evaluation of pea protein isolate as alternative protein source in diets for juvenile tilapia (Oreochromis niloticus). Aquac Res 38:537-545

Stickney RR (1997) Tilapia nutrition, feeds and feeding. In: Costa-Pierce BA, Rakocy JE (eds) Tilapia aquaculture in the Americas. World Aquaculture Society, Baton Rouge

Terova G, Corà S, Verri T, Rimoldi S, Bernardini G, Saroglia M (2009) Impact of feed availability on PepT1 mRNA expression levels in sea bass (Dicentrarchus labrax). Aquaculture 294:288-299

Verri T, Terova G, Dabrowski K, Saroglia M (2011) Peptide transport and animal growth: the fish paradigm. Biol Lett 7:597-600

Zambonino Infante JL, Cahu CL (2007) Dietary modulation of some digestive enzymes and metabolic processes in developing marine fish: applications to diet formulation. Aquaculture 268:98-105

Zambonino Infante JL, Cahu CL, Péres A (1997) Partial substitution of native fish meal protein by di- and tripeptides in diet improves sea bass (Dicentrarchus labrax) larvae development. J Nutr 127:608-614 